\title{
Mannan-protein Location and Biosynthesis in Plasma Membranes from the Yeast Form of Candida albicans
}

\author{
By M. S. MARRIOTT* \\ Sub-Department of Chemical Microbiology, Department of Biochemistry, \\ University of Cambridge, Cambridge $C B 2 \mathrm{I} Q W$
}

(Received 7 April I977)

\begin{abstract}
Specific labelling of the plasma membrane of intact protoplasts from Candida albicans, using lactoperoxidase-catalysed iodination, has permitted the development of a procedure for isolating relatively pure preparations of this component. The specific activity of the labelled membrane was very low, indicating that only a few proteins are exposed on the outer membrane surface. The specific activity of labelling increased almost Ioo-fold when both membrane surfaces were exposed to iodination. Sodium dodecyl sulphate-polyacrylamide gel electrophoresis, in combination with autoradiography, indicated that only two glycosylated proteins are exposed on the outer membrane surface, whilst all membrane proteins can be labelled in isolated plasma membrane preparations. Extraction of mannanprotein from purified cell walls of $C$. albicans gave material which, on sodium dodecyl sulphate-polyacrylamide gel electrophoresis, resembled the exposed plasma membrane glycoproteins.

Purified plasma membranes incorporated mannose from GDPmannose on to an endogenous protein acceptor. The addition of exogenous cell wall mannan-protein increased the degree of incorporation. Approximately $12 \%$ of the incorporated mannose was sensitive to $\beta$-elimination, but a lipid intermediate was not involved in the reaction. An Arrhenius plot of enzyme activity at different temperatures showed a discontinuity at $17{ }^{\circ} \mathrm{C}$. The mannan synthetase activity was also significantly less at $40^{\circ} \mathrm{C}$ than at $37^{\circ} \mathrm{C}$, temperatures at which the yeast-mycelial transition has been found to occur in this organism. The possible biosynthetic relationship between the exposed glycoproteins of the plasma membrane and those of the cell wall is discussed.
\end{abstract}

\section{INTRODUCTION}

The use of non-penetrant covalent labels for 'tagging' plasma membranes has proved a valuable aid in the isolation of this component from a number of eukaryotic organisms (Wallach \& Lim, 1973). The iodination of immunoglobulins by purified lactoperoxidase was first described by Marchalonis ( 1969 ) and this has provided a widely used technique for the specific radioactive labelling of plasma membranes from a number of organisms (Phillips \& Morrison, I970; Poduslo, Greenberg \& Glick, 1972), including the yeasts Saccharomyces cerevisiae (Schibeci, Rattray \& Kidby, I973a; Duran, Bowers \& Cabib, I975) and Candida albicans (Marriott, I975a). Lactoperoxidase-catalysed iodination of intact cells lacking a cell wall can also be used to demonstrate the asymmetric distribution of membrane proteins across the plane of the lipid bilayer (Poduslo et al., 1972; Phillips \& Morrison, I97I; Salton, Schor \& Ng, 1972). However, the use of this technique and the interpretation of the results obtained are open to criticism unless stringent precautions are taken (Morrison, 1974).

* Present address: Fachbereich Biologie und Vorklinische Medizin, Institut für Botanik, Universität Regensburg, 8400 Regensburg, Universitätsstrasse 31, West Germany. 
Following the reports of Schibeci et al. (1973a,b), it was found that relatively pure preparations of plasma membrane could be isolated from disrupted protoplasts of $C$. albicans using differential and discontinuous sucrose density gradient flotation centrifugation (Marriott, I975a). The position of the plasma membrane on the gradients was determined by radioassay. The possibility therefore existed for identifying the plasma membrane proteins and studying their disposition in this organism. Chemical analysis indicated the presence of polysaccharides, perhaps as glycoproteins, which are enriched in mannose, compared with the cell wall (Marriott, I975a).

The structure of baker's yeast cell wall mannan-protein has been studied extensively (Ballou, I974; Nakajima \& Ballou, 1974) and a complex enzymic mechanism for its biosynthesis has been proposed (Nakajima \& Ballou, 1975). At least some of the enzymes involved, as well as the endogenous protein acceptor, appear to be membrane-bound (Lehle \& Tanner, 1974; Sharma et al., 1974). The type of membrane involved is unknown, although mannan synthetase activity has been found in purified preparations of plasma membrane from $C$. albicans (Marriott, 1975b). This paper presents evidence for the nature and disposition of the proteins in the plasma membrane of $C$. albicans. In addition the possible relationship between the plasma membrane and cell wall mannan-proteins has been studied together with the properties of the membrane-bound mannan synthetase.

\section{METHODS}

Organism and growth. Candida albicans 6406 was maintained and grown as described previously (Marriott, 1975a). Cells were harvested in the mid-exponential phase of growth and protoplasts were prepared using a lytic enzyme preparation from Streptomyces violaceus with $1 \cdot 2 \mathrm{M}$-sorbitol (final concentration) as osmotic stabilizer.

Iodination. A modification of the procedure described by Marriott (1975a) was used in an attempt to increase the specific activity of the product. Protoplasts were resuspended in $5 \mathrm{ml} 50 \mathrm{~mm}$-citrate/phosphate buffer, $\mathrm{pH} 7 \cdot 4$, containing $\mathrm{I} \cdot 2 \mathrm{M}$-sorbitol, at a density equivalent to Ioo $\mathrm{mg}$ dry wt cells $\mathrm{ml}^{-1}$. Lactoperoxidase (Sigma) and $\mathrm{Na}^{125} \mathrm{I}$ (The Radiochemical Centre, Amersham) made up in io $\mu \mathrm{M}-\mathrm{Na}_{2} \mathrm{SO}_{3}$ were added to final concentrations of $0.2 \mu \mathrm{M}$ and $40 \mathrm{nCi} \mathrm{ml}^{-1}$, respectively. The protoplasts were incubated at $37^{\circ} \mathrm{C}$ and six Io $\mu \mathrm{l}$ additions of $10 \mu \mathrm{M}-\mathrm{H}_{2} \mathrm{O}_{2}$ were made at 2 min intervals. After a total incubation of $15 \mathrm{~min}$, the protoplasts were washed six times in the stabilized buffer, lysed in a large volume of $100 \mathrm{~mm}-\mathrm{Tris} / \mathrm{HCl}$ buffer, $\mathrm{pH} 7 \cdot 2$, containing $10 \mathrm{mM}-\mathrm{MgCl}_{2}$ and fractionated as described previously (Marriott, $1975 a$; Fig. I). Control incubations ( $\mathrm{I} \mathrm{ml}$ volume, otherwise identical conditions) without $\mathrm{H}_{2} \mathrm{O}_{2}$ and/or lactoperoxidase were performed simultaneously. Samples were removed during the fractionation procedure for determination of radioactivity.

The proportion of radioactivity precipitable by $5 \%(\mathrm{w} / \mathrm{v})$ trichloroacetic acid (TCA) was determined by collecting the precipitate on membrane filters (Oxoid) and washing three times with $5 \mathrm{ml} \mathrm{I} \%(\mathrm{v} / \mathrm{v})$ acetic acid. Radioactivity determinations were made using a Packard 3383 scintillation spectrometer and scintillant containing 5 g 2,5-diphenyloxazole $1^{-1}$ in Triton X-Ioo/toluene $(\mathrm{I}: 2, \mathrm{v} / \mathrm{v})$. Purified plasma membrane preparations, which had been labelled from the outside, were subjected to further radioactive labelling to identify those proteins exposed on the inner membrane surface. The procedure used was similar to that described for intact protoplasts, except that a smaller ( $\mathrm{r} \mathrm{ml}$ ) incubation volume was used.

Sodium dodecyl sulphate-polyacrylamide gel electrophoresis. Polyacrylamide slab gels were constructed as follows. The separating gel was prepared from $10 \mathrm{ml}$ solution A (I M-HCl, $48 \mathrm{ml}$; Tris, $36 \cdot 3 \mathrm{~g} ; N, N, N^{\prime}, N^{\prime}-$ tetramethyl-I, 2-diaminoethane, $0.23 \mathrm{ml} ; \mathrm{H}_{2} \mathrm{O}$ to $100 \mathrm{ml}$ ), $13.3 \mathrm{ml}$ solution $\mathrm{B}$ (acrylamide, $30 \mathrm{~g}$; bisacrylamide, $390 \mathrm{mg} ; \mathrm{H}_{2} \mathrm{O}$ to $100 \mathrm{ml}$ ), $16.9 \mathrm{ml} \mathrm{H}_{2} \mathrm{O}, 0.4 \mathrm{ml}$ I0\% (w/v) sodium dodecyl sulphate (SDS), and $0.4 \mathrm{ml}$ I0\% (w/v) ammonium persulphate. The stacking gel was made from $2.5 \mathrm{ml}$ solution $\mathrm{B}, \mathrm{r} \cdot 875 \mathrm{ml}$ solution $\mathrm{C}$ (I $\mathrm{M}-\mathrm{HCl}, 48 \mathrm{ml}$; Tris, $5.98 \mathrm{~g} ; N, N, N^{\prime}, N^{\prime}$-tetramethyl-I,2-diaminoethane, $0.46 \mathrm{ml} ; \mathrm{H}_{2} \mathrm{O}$ to $100 \mathrm{ml}$ ), $10 \mathrm{ml}$ $\mathrm{H}_{2} \mathrm{O}, 0.15 \mathrm{ml} 10 \%$ SDS and $0.15 \mathrm{ml} 10 \%$ ammonium persulphate. The gels were run at a constant current of $40 \mathrm{~mA}$; the electrophoresis buffer (Tris, $\mathrm{I} \cdot 5 \mathrm{~g}$; glycine, $7 \cdot 2 \mathrm{~g} ; \mathrm{H}_{2} \mathrm{O}$ to $1 \mathrm{l}$ ) contained $0 . \mathrm{I} \%$ SDS and bromophenol blue as tracking dye.

Protein samples for electrophoresis were solubilized at a concentration of $\mathrm{I} \mathrm{mg} \mathrm{ml} \mathrm{m}^{-1}$ in a mixture containing: I \% (w/v) SDS, $250 \mu \mathrm{M}$-phenylmethylsulphonyl fluoride, 25 mM-dithiothreitol, I mM-EDTA, and $5 \%(\mathrm{w} / \mathrm{v})$ sucrose. Samples were incubated at $45^{\circ} \mathrm{C}$ for $30 \mathrm{~min}$ and insoluble material was removed by centrifugation. Between 100 and $200 \mu \mathrm{g}$ protein was applied per sample well.

After electrophoresis, the gels were fixed and the proteins were stained using the shorter procedure of Fairbanks, Steck \& Wallach (1971). Glycoproteins were stained using the periodate-Schiff reagent (Fairbanks et al., 1971). 


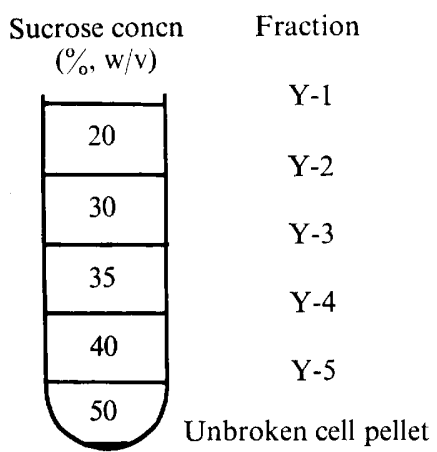

Fig. I. Discontinuous sucrose density gradient used to fractionate the $5000 \mathrm{~g}$ pellet from lysed protoplasts of Candida albicans. The gradients were made up in $3 \times \mathrm{I}$ in cellulose nitrate ultracentrifuge tubes and centrifuged for $3 \mathrm{~h}$ at $82000 \mathrm{~g}$ (av.) in an SW27 rotor, using a Beckman L5 50 ultracentrifuge. The position of the fractions mentioned in the text is indicated.

Autoradiography. After being photographed, the stained gels were dried down under reduced pressure on to Whatman $3 \mathrm{MM}$ chromatography paper. They were covered with a sheet of Kodak Blue brand X-ray film and stored between glass plates until sufficient blackening of the film was observed after development in Ilford contrast FF.

Preparation of mannan-protein. Cell walls of Candida albicans were prepared using a Braun model MSK homogenizer (Braun, Melsungen, West Germany). After washing and lipid extraction, wall glycoproteins were extracted by the method of Falcone \& Nickerson (1956). The solubilized material was extensively dialysed against distilled water before being freeze-dried. The lyophilized mannan-protein was redissolved in $12 \mathrm{ml}$ distilled water and any insoluble material (putative glucan-protein) was collected by centrifugation.

Bulk plasma membrane preparation. Plasma membranes were also prepared by disrupting the cells in the Braun homogenizer. Walls were removed by centrifuging at $1000 \mathrm{~g}$ for $5 \mathrm{~min}$ and crude membranes were sedimented at $10000 \mathrm{~g}$ for $30 \mathrm{~min}$. This preparation was then fractionated by discontinuous sucrose density gradient flotation centrifugation as above.

Mannose incorporation. The incorporation of mannose from GDP $\left[{ }^{14} \mathrm{C}\right]$ mannose (The Radiochemical Centre, Amersham) was measured using incubation mixtures which each contained (in $30 \mu \mathrm{l}): 5 \mathrm{~mm}$-Tris/ $\mathrm{HCl}$ $\left(\mathrm{pH} \mathrm{7.4)} ; 7 \mathrm{~mm}-\mathrm{MgCl}_{2} ; 5 \mathrm{mM}-\mathrm{MnCl}_{2} ; 0.2 \mathrm{mM}-\mathrm{GDP}\left[{ }^{14} \mathrm{C}\right]\right.$ mannose (100 $\mathrm{nCi}$ ); and 20 to $50 \mu \mathrm{g}$ protein. The reaction was allowed to proceed at $37^{\circ} \mathrm{C}$ and stopped after suitable incubation periods by adding $0.2 \mathrm{ml}$ 10 \% (w/v) TCA. The precipitate was collected by filtration, washed and assayed for radioactivity (Lehle \& Tanner, 1974).

The ability of the membrane preparation to use exogenous acceptors was tested by incorporating mannose (20 $\mathrm{mm}$ ) or C. albicans cell wall mannan-protein into the incubation mixture. When mannose was the exogenous acceptor, the reaction was stopped by adding $0.2 \mathrm{ml}$ ethanol and the products were separated by thin-layer chromatography.

To determine the nature of the products of the reaction samples of the TCA precipitate were subjected to either $\beta$-elimination $\left(24 \mathrm{~h}, 2 \mathrm{I}{ }^{\circ} \mathrm{C}, \mathrm{O} \cdot \mathrm{I} \mathrm{M}-\mathrm{NaOH}\right)$ or acid hydrolysis $\left(\mathrm{I} \mathrm{h}, 105{ }^{\circ} \mathrm{C}, 3 \mathrm{M}-\mathrm{HCl}\right)$. Following $\beta$-elimination, the reaction mixture was neutralized and dialysed. Both diffusible and non-diffusible material were assayed for radioactivity. Acid hydrolysates were evaporated to dryness over $\mathrm{NaOH}$, taken up in a small volume of water and separated by thin-layer chromatography.

Incorporation into lipid-soluble material was measured by stopping the reaction with $0.5 \mathrm{ml}$ chloroform/ methanol $(2: \mathrm{I}, \mathrm{v} / \mathrm{v})$. Lipid-soluble radioactivity was extracted as described by Gold \& Hahn (I976). The effect of temperature on the functioning of the enzyme preparation was studied by carrying out incubations at a range of temperatures from 0 to $40^{\circ} \mathrm{C}$.

Other analytical methods. After acid hydrolysis and neutralization (Marriott, 1975 a), concentrated samples of mannan-protein were applied to Whatman no. I chromatography paper and separated by descending chromatography using butan-I-ol/acetic acid/water (3:I:I, by vol.) as solvent (Sentandreu \& Northcote, 1969). Chromatograms were stained using the Wilson dip (Wilson, 1959) and sugars were identified by comparing their $R_{F}$ values with those of standards. Thin-layer chromatography was performed using precoated plastic plates (Camlabs, Cambridge) in the following solvent systems: butan-r-ol/ethyl acetate/acetic acid/water (40:30:25:40, by vol.) and ethyl acetate/pyridine/water $(5: 3: 2$, by vol.). The thin-layer plates were cut into $2 \mathrm{~mm}$ sections and assayed for radioactivity.

Protein was assayed by measuring the $E_{280} / E_{260}$ ratio. 
Table I. Lactoperoxidase-catalysed ${ }^{125}$ I iodination of intact protoplasts of Candida albicans and the percentage distribution of radioactivity associated with membranous material from the $5000 \mathrm{~g}$ pellet after osmotic lysis

The results are the means of three experiments; standard deviations are given.

\begin{tabular}{|c|c|c|c|c|}
\hline & & & & \\
\hline & & No $\mathrm{H}_{2} \mathrm{O}_{2}$ & $\begin{array}{c}\mathrm{No}_{2} \mathrm{O}_{2} \text { or } \\
\text { lactoperoxidase }\end{array}$ & Experimental \\
\hline $\begin{array}{l}\text { Washed } \\
\text { (TCA-p }\end{array}$ & $\begin{array}{l}\text { sts } \\
\text { ed c.p.m.) }\end{array}$ & $I \cdot 7 \pm 0.3 \times 10^{3}$ & $7 \cdot 4 \pm 0.5 \times 10^{2}$ & $3.1 \pm 0.4 \times 10^{5}$ \\
\hline $\begin{array}{l}\text { Incorpor } \\
\text { radioact }\end{array}$ & & $0.0062 \pm 0.0009$ & $0.0039 \pm 0.0003$ & $0.21 \pm 0.02$ \\
\hline Fraction & $\begin{array}{c}\text { Total c.p.m. } \\
(\%)\end{array}$ & $\begin{array}{l}\text { TCA-precipitated } \\
\text { c.p.m. (\%) }\end{array}$ & $\begin{array}{r}\mathrm{IO}^{-2} \times \\
\text { [TCA-precipitat }\end{array}$ & $\begin{array}{l}\text { (mg protein })^{-1} \text { ] }\end{array}$ \\
\hline $\begin{array}{l}Y-I \\
Y-2 \\
Y-3 \\
Y-4 \\
Y-5\end{array}$ & $\begin{array}{l}\quad 5 \pm 4 \\
\text { II } \pm 2 \\
\text { I } 2 \pm 6 \\
\text { I } 5 \pm 10 \\
57 \pm 14\end{array}$ & $\begin{array}{l}7 \pm 5 \\
11 \pm 1 \\
\text { I } 3 \pm 6 \\
13 \pm 10 \\
57 \pm 12\end{array}$ & & \\
\hline
\end{tabular}

\section{RESULTS}

\section{Distribution of radioactivity after iodination}

The distribution of ${ }^{125} \mathrm{I}$ on fractionation of labelled protoplasts from $C$. albicans is shown in Table I. In the absence of hydrogen peroxide and/or lactoperoxidase, little, if any, labelling took place $(0.0062 \%$ and $0.0039 \%$ compared with $0.21 \%)$. Some 65 to $70 \%$ of the TCA-precipitable radioactivity was sedimented at $5000 \mathrm{~g}$ and after fractionation of this pellet, most radioactivity (approximately 60\%) was associated with membranous material sedimenting in band Y-5 (Fig. I). This fraction also had the highest specific activity (Table I). Exact recoveries of protein and radioactivity were not measured due to the variation in sample sizes during fractionation, but approximate recoveries were between 60 and $80 \%$.

When the material from each of the five bands was run on identical discontinuous sucrose gradients, a redistribution of both protein and radioactivity took place. The amount of radioactivity associated with fractions other than $\mathrm{Y}-5$ varied greatly. This was simply due to the extremely low radioactivity of the material found in these bands and the consequent large counting error. After two centrifugations, most of this radioactivity was found in the sucrose, indicating that it was originally trapped inside membranous vesicles. Only that material from band Y-5 which re-ran in position 5 did not lose its radioactivity; indeed, it showed an increase in specific activity [to $4.8 \times 10^{3}$ TCA-precipitable c.p.m. $(\mathrm{mg} \text { protein })^{-1}$. Some 6 to $10 \%$ of the protein in the $5000 \mathrm{~g}$ pellet (representing approximately $17 \mathrm{mg}$ protein) was recovered in band Y-5 after two centrifugations.

Attempts to increase the specific activity of the labelled plasma membrane by modifying the experimental conditions were unsuccessful, indicating that there was only a small number of exposed sites (tyrosine residues). This is in marked contrast to the results obtained when purified plasma membranes (Y-5) were relabelled using identical experimental conditions. In this case the specific activity was increased approximately roo-fold [to $4.2 \times 10^{5}$ TCA-precipitable c.p.m. (mg protein) ${ }^{-1}$ ]. It appears, therefore, that isolation of the plasma membrane, which exposes the inner membrane surface, greatly increases the number of proteins available for labelling. 


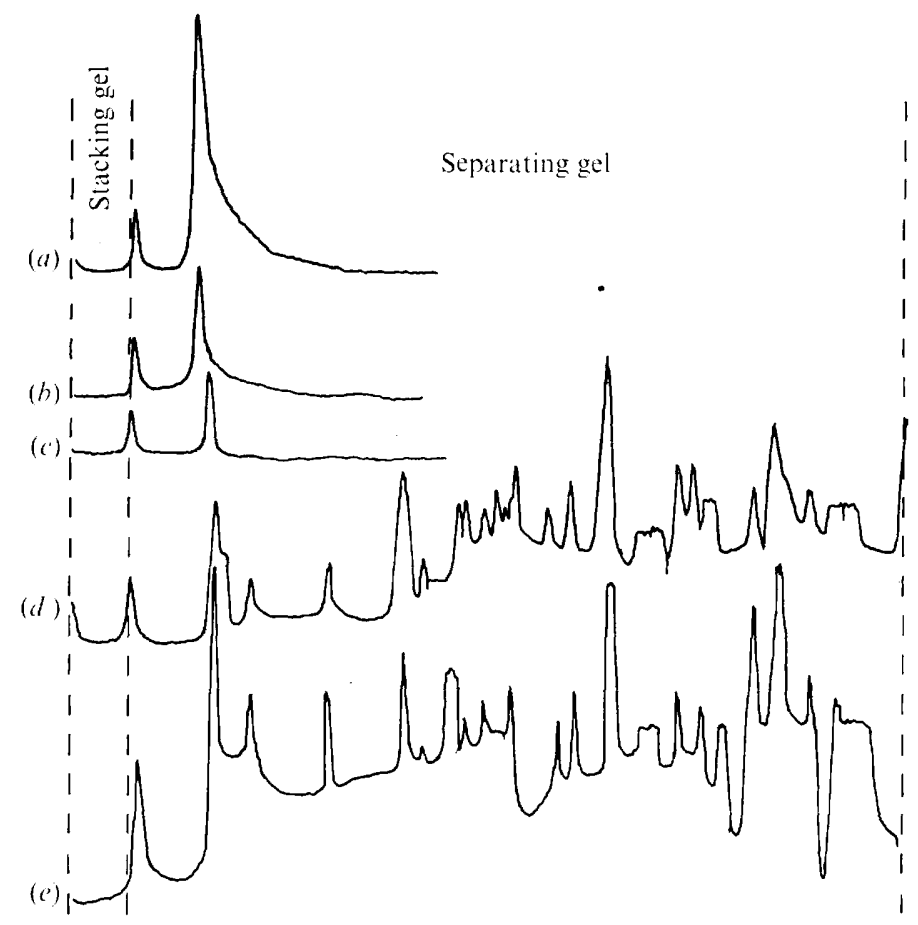

Fig. 2. Densitometer traces of sodium dodecyl sulphate-polyacrylamide gels: (a) Candida albicans cell wall mannan-protein isolated by the method of Falcone \& Nickerson (1956), stained for protein or carbohydrate; $(b)$ purified plasma membranes from $C$. albicans, stained for carbohydrate; $(c)$ autoradiogram of purified plasma membranes isolated from protoplasts which had been labelled with ${ }^{125}$ I whilst intact; $(d)$ purified plasma membranes, stained for protein; $(e)$ autoradiogram of purified plasma membranes further labelled with ${ }^{125} \mathrm{I}$ after isolation.

\section{Gel electrophoresis pattern and autoradiography}

Figure $2(d)$ shows a densitometer trace of the proteins present in purified plasma membranes from $C$. albicans. A large number of major and minor bands can be observed, some of which were stained by the periodate-Schiff procedure, indicating that they are glycoproteins (Fig. $2 b$ ). Autoradiography of samples of plasma membrane iodinated on the outer surface showed that only two glycoprotein bands were labelled (Fig. 2c). However, when membranes were iodinated on both surfaces, all proteins were labelled (Fig. $2 e$ ). The two glycoproteins exposed on the outer membrane surface run in a similar position to glycoproteins extracted from the cell wall (Fig. 2a).

\section{Characterization of mannan-protein}

Attempts to isolate mannan-protein from cell walls of $C$. albicans using the I,2-diaminoethane technique (Korn \& Northcote, I960) were unsuccessful, although this had been reported previously (Kolarova, Masler \& Sik1, 1973). A fraction containing mannose and protein was isolated, but gel electrophoresis indicated that the two components were no longer covalently linked. Alkali extraction (Falcone \& Nickerson, 1956) yielded a watersoluble fraction containing mainly mannose but also a faster running component, possibly a tetrose. The insoluble 'glucan-protein' (Falcone \& Nickerson, I956) had a similar composition and gave an identical gel electrophoresis profile to the soluble cell wall glycoproteins. It seems likely that this is denatured mannan-protein. 
Table 2. Effect of exogenous mannan-protein on the incorporation of mannose from GDPmannose by purified plasma membranes from Candida albicans

The results are the mean of at least three determinations; standard deviations are given.

\begin{tabular}{|c|c|c|c|}
\hline Experiment & $\begin{array}{c}\mathrm{IO}^{-3} \times \text { Specific activity } \\
{\left[\text { c.p.m. } \mathrm{min}^{-1}(\mathrm{mg} \text { protein })^{-1}\right]}\end{array}$ & $\begin{array}{c}\text { Radioactivity } \\
\text { released by } \\
\beta \text {-elimination }(\%)\end{array}$ & $\begin{array}{c}\text { Radioactivity } \\
\text { extractable by } \\
\text { chloroform/methanol }(\%)\end{array}$ \\
\hline $\begin{array}{l}\text { Control (mem- } \\
\text { branes only) }\end{array}$ & $2 \cdot 0 \pm 0 \cdot 2$ & II \pm 2 & $0.7 \pm 0.4$ \\
\hline Mannan-protein & $2 \cdot 4 \pm 0.1$ & $12 \pm 3$ & Not tested \\
\hline
\end{tabular}

Mannose incorporation

During tests of 60 min duration, purified plasma membranes incorporated ${ }^{14} \mathrm{C}$ from GDP $\left[{ }^{14} \mathrm{C}\right]$ mannose into TCA-precipitable material (glycoprotein) in a linear fashion with time. Acid hydrolysis of the product formed, followed by thin-layer chromatography, revealed that the radioactivity incorporated was entirely in the form of mannose. Approximately $10 \%$ of the radioactivity could be removed by $\beta$-elimination, conditions under which only $O$-glycosidic bonds are broken (Table 2). Less than I \% of the radioactivity could be extracted by chloroform/methanol, suggesting that little or no lipid intermediate was present in the reaction.

The addition of exogenous mannan-protein resulted in a stimulation of activity (Table 2). When mannose was the acceptor, radioactivity was detected on thin-layer chromatograms in positions corresponding to short-chain oligomannoses. However, since standards were not available for identifying these components, estimations of the percentage stimulation were thought invalid.

The effect of temperature on the activity of the enzyme preparation is shown in Fig. 3, in the form of an Arrhenius plot. A discontinuity was observed at $17{ }^{\circ} \mathrm{C}$ and also a loss of activity above $37^{\circ} \mathrm{C}$.

\section{DISCUSSION}

The isolation of pure preparations of plasma membrane from eukaryotic organisms is a difficult procedure, complicated by the presence of other, internal membranes. Radioactive labelling of the cell surface facilitates the localization and identification of this component during fractionation. The results obtained using lactoperoxidase-catalysed iodination indicate that relatively pure samples of plasma membranes can be isolated from C. albicans protoplasts. Fractionation on a single discontinuous sucrose gradient yields a product heavily contaminated with other membranous components. This is probably due to entrapment of membrane vesicles and a second centrifugation is required to give a pure preparation. A third passage through a sucrose gradient did not result in a further redistribution of protein or radioactivity.

The presence of radioactivity in bands other than Y-5 (plasma membrane) may be due to two factors: the presence of unreacted ${ }^{125} \mathrm{I}$, and the presence of trapped plasma membrane. Both appear equally likely, since much of the associated radioactivity is released into the buffered sucrose on recentrifugation and is not TCA-precipitable, and there is also an appreciable redistribution of protein from all bands. Much of the radioactivity found in band $\mathrm{Y}-5$ re-runs in position 5 after two centrifugations and the increase in specific activity indicates that purification has taken place. Gel electrophoresis of solubilized plasma membrane, iodinated on the outer surface only, shows two labelled glycoproteins, one of which barely enters the separating gel, a situation analogous to animal cells (Phillips \& Morrison, I97I; Poduslo et al., I972). The anomalous behaviour of glycoproteins on gel electrophoresis prevents an accurate molecular weight determination, and each labelled component may represent more than one protein (Phillips \& Morrison, 1971). The fact that all membrane 


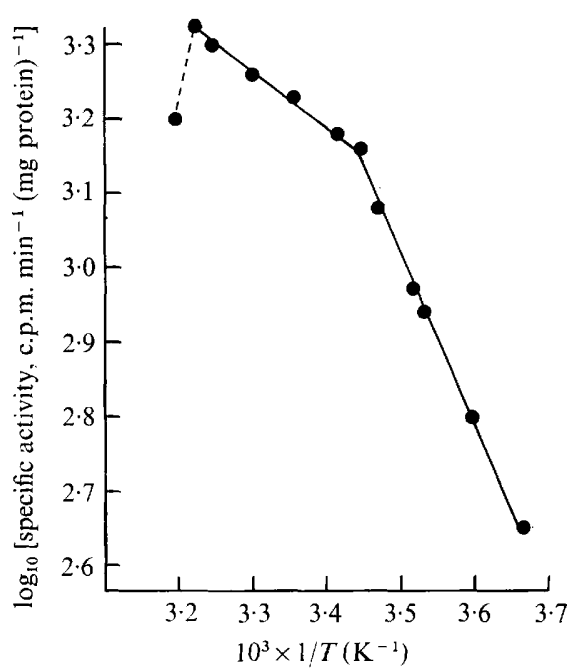

Fig. 3. Effect of temperature on the rate of incorporation of mannose from GDPmannose by purified plasma membranes from the yeast form of Candida albicans. The results are the means of three determinations and are plotted in the form of an Arrhenius plot.

proteins are available to the lactoperoxidase enzyme when both surfaces are exposed, but only two when the outer surface is labelled, is evidence for the asymmetric distribution of proteins across the plane of the plasma membrane of $C$. albicans.

Isolated mannan-protein from the wall of this organism gives two components on gel electrophoresis, both of which are heavily stained with the periodate-Schiff procedure. Again one component barely enters the separating gel, whilst both appear to correspond to the two exposed glycoproteins of the plasma membrane.

The structure of the cell wall mannan-protein of $C$. albicans is not known in as much detail as that from Saccharomyces cerevisiae (Sik1, Masler \& Bauer, 1965). However, additional information can be inferred from the mannose incorporation data. A proportion of the mannose residues is linked to the protein via $O$-glycosidic linkages, whilst the remainder is not sensitive to $\beta$-elimination and is attached via $N$-glycosidic linkages. Work in this laboratory also indicates that the mannan-protein contains phosphorylated mannose residues (J. E. Cope, personal communication). It seems likely, therefore, that $C$. albicans mannan-protein resembles that of $S$. cerevisiae and is synthesized by a similar mechanism.

Previous work with S. cerevisiae (Sharma et al., 1974) has shown that the attachment of the first mannose residues to the protein occurs via a lipid intermediate (dolichol). However, Lehle \& Tanner (1974) did not find that this intermediate participated in mannan biosynthesis when crude plasma membrane preparations were used. A similar result has been obtained with $C$. albicans, which is in contrast to the results obtained studying the incorporation of mannose into growing cells. In this case 8 to $10 \%$ of the mannose was found to be lipid-soluble (Marriott, unpublished data). It appears, therefore, that those mannose residues which are attached to the protein via a lipid intermediate are added before the glycoprotein reaches the plasma membrane. However, further mannosylation reactions can occur at the plasma membrane level. From the evidence that a membranebound protein acceptor is involved in mannan-protein biosynthesis (Lehle \& Tanner, 1974; Sharma et al., 1974), it seems reasonable to suggest that there is a biosynthetic relationship between the exposed glycoproteins of the plasma membrane and the wall mannan-protein. Recent work by Horisberger, Rosset \& Bauer (1976) on the localization of mannan at the surface of yeast protoplasts also supports this view. 
The effect of temperature on the membrane-bound enzyme is important in two respects. Firstly, the break in the Arrhenius plot indicates that the enzyme is sensitive to its lipid environment (Wilson, Rose \& Fox, 1970). Thus, altering the fatty-acid composition of the membrane may effect wall biosynthesis, evidence for which has been presented by Douglas et al. (1975) with S. cerevisiae. Secondly, Chattaway, Holmes \& Barlow (1968) have shown that temperature is important in controlling the yeast-mycelial transition in C. albicans. Under appropriate growth conditions, at $37^{\circ} \mathrm{C}$ the yeast form is induced, whilst at $40^{\circ} \mathrm{C}$ the mycelial form predominates. These workers have also shown changes in wall composition associated with this transition. The sensitivity of plasma membrane-bound mannan synthetase to temperature indicates that it may play a role in dimorphism in this organism.

It has been suggested that proteins may be lost from the plasma membrane during protoplast formation and that this may influence the observed asymmetric distribution. The likely relationship between some plasma membrane and wall glycoproteins, as well as the presence of secreted enzymes, makes it difficult to define what is meant by the word 'protoplast'. I prefer to use this term rather than 'sphaeroplast', but do so simply as a working definition for the cells remaining after cell wall lysis by 'strepzymes'. Until it is possible to identify and determine which proteins belong to the plasma membrane and which to the cell wall, the above question, although valid, cannot be answered.

The author is grateful to the Medical Research Council for providing financial support.

\section{REFERENCES}

BALlou, C. E. (1974). Some aspects of the structure, immunochemistry and genetic control of yeast mannans. Advances in Enzymology 40, 239-270.

Chattaway, F. W., Holmes, M. R. \& Barlow, A. J. E. (I968). Cell wall composition of the mycelial and blastospore forms of Candida albicans. Journal of General Microbiology $\mathbf{5}^{\mathbf{r}}$, 367-376.

Douglas, L. J., Atkinson, D. M., Hossack, J. A \& Rose, A. H. (I975). A possible role for lipid unsaturation in the biosynthesis of wall polymers in Saccharomyces cerevisiae. Abstracts, Fourth International Symposium on Yeast and Other Protoplasts, p. 7I. Leicester: Cave Printing Group.

Duran, A., Bowers, B. \& CABIB, E. (1975). Chitin synthetase zymogen is attached to the yeast plasma membrane. Proceedings of the National Academy of Sciences of the United States of America 72, 3952-3955.

Fairbanks, G., Steck, T. L. \& Wallach, D. F. H. (197I). Electrophoretic analysis of the major polypeptides of the human erythrocyte membrane. Biochemistry ro, 2606-2617.

Falcone, G. \& Nickerson, W. J. (1956). Cell wall mannan-protein of Baker's yeast. Science 124, 272-273.

Gold, M. H. \& HaHN, H. J. (1976). Role of a mannosyl lipid intermediate in the synthesis of Neurospora crassa glycoproteins. Biochemistry $\mathbf{1 5}_{5}$, I 808-I814.

Horisberger, M., Rosset, J. \& Bauer, H. (I976). Localization of mannan at the surface of yeast protoplasts by scanning electron microscopy. Archives of Microbiology rog, 9-14.

Kolarova, N., Masler, L. \& SiKL, D. (1973). Cell wall glycoproteins of Candida albicans serotypes
A and B. Biochimica et biophysica acta 328, 22 I-227.

Korn, E. D. \& Northcote, D. H. (1960). Physical and chemical properties of polysaccharides and glycoproteins of the yeast cell wall. Biochemical Journal 75, I2-I7.

LeHLE, L. \& TANNER, W. (1974). Membrane bound mannosyl transferases in yeast glycoprotein biosynthesis. Biochimica et biophysica acta 350, 225-235.

MaRChalonis, J. J. (1969). An enzymic method for the trace iodination of immunoglobulins and other proteins. Biochemical Journal 113, 299-305.

MARRIOTT, M. S. (I975a). Isolation and chemical characterization of plasma membranes from the yeast and mycelial forms of Candida albicans. Journal of General Microbiology 86, I I 5-I 32.

MarriotT, M. S. (1975b). Enzymic activity of purified plasma membranes from the yeast and mycelial forms of Candida albicans. Journal of General Microbiology 89, 345-352.

Morrison, M. (I974). The determination of the exposed proteins on membranes by the use of lactoperoxidase. Methods in Enzymology 32B, I03-109.

NAKAJIMA, T. \& Ballou, C. E. (1974). Structure of the linkage region between the polysaccharide and protein parts of Saccharomyces cerevisiae mannan. Journal of Biological Chemistry 249, 7685-7694.

NaKaJima, T. \& Ballou, C. E. (1975). Yeast manno-protein biosynthesis; solubilization and selective assay of four mannosyl transferases. Proceedings of the National Academy of Sciences of the United States of America 72, 39123916. 
Phillips, D. R. \& Morrison, M. (1970). The arrangement of proteins in the human erythrocyte membrane. Biochemical and Biophysical Research Communications 40, 284-289.

Phillips, D. R. \& Morrison, M. (I97I). Exposed proteins of the intact human erythrocyte. Biochemistry ro, I766-I 77I.

Poduslo, J. F., Greenberg, C. S. \& Glick, M. C. (I972). Proteins exposed on the surface of mammalian cell membranes. Biochemistry II, 2616-2621.

Salton, M. R. J., Schor, M. T. \& NG, M. H. (1972). Internal localization of Micrococcus lysodeikticus membrane ATPase by iodination with ${ }^{125}$ I. Biochimica et biophysica acta 290, 408-413.

Schibeci, A., Rattray, J. B. M. \& Kidby, D. K. (1973a). Isolation and identification of yeast plasma membrane. Biochimica et biophysica acta 3rI, I5-25.

Schibeci, A., Rattray, J. B. M. \& Kidby, D. K. $(\mathrm{I} 973 \mathrm{~b})$. Electron microscope autoradiography of labelled yeast plasma membrane. Biochimica et biophysica acta 323, 532-538.
Sentandreu, R. \& Northcote, D. H. (I969). The characterization of oligosaccharides attached to threonine and serine in a mannan-protein obtained from the cell wall of yeast. Carbohydrate Research 100, 584-585.

Sharma, C. B., Babczinski, P., Lehle, L. \& TANNER, W. (I974). The role of dolichol monophosphate in glycoprotein biosynthesis in Saccharomyces cerevisiae. European Journal of Biochemistry 46, 35-4I.

Sikl, D., Masler, L. \& Bauer, S. (I965). The polysaccharides of yeasts and yeast-like microorganisms I: the extracellular surface mannan of Candida albicans Berkhout. Chemicke zvesti r9, 2 I-27.

WAllach, D. F. H. \& LIM, P. S. (I973). A critical evaluation of plasma membrane fractionation. Biochimica et biophysica acta 200, 2 I I-254.

WILSON, C. (1959). Quantitative determination of sugars on paper chromatograms. Analytical Chemistry 3r, I 199-r20I.

Wilson, G., Rose, S. P. \& Fox, C. F. (1970). The effect of membrane lipid unsaturation on glycoside transport. Biochemical and Biophysical Research Communications 38, 61 7-623. 